\title{
OPTIC ATROPHY WITH ALTITUDINAL HEMIANOPIA IN NEUROFIBROMATOSIS*
}

\author{
BY \\ B. SHEEHAN \\ County Hospital, York
}

INVOLVEMENT of the optic nerve in generalized neurofibromatosis is rare compared with affections of the peripheral and acoustic nerves. It may either show itself as a unilateral proptosis, loss of sight, and disk changes, as in a typical orbital tumour, or occur, without proptosis, as part of the "chiasmal syndrome" of Cushing. Although neurofibromatosis was first described by Smith (1849), and though it is now almost 80 years since the first recognition (Michel, 1873) that an optic-nerve tumour can occur in the disease, only about 55 reports of this are to be found in the literature so far. The case here described is therefore of unusual interest, although the description is necessarily only a clinical one.

\section{Case Report}

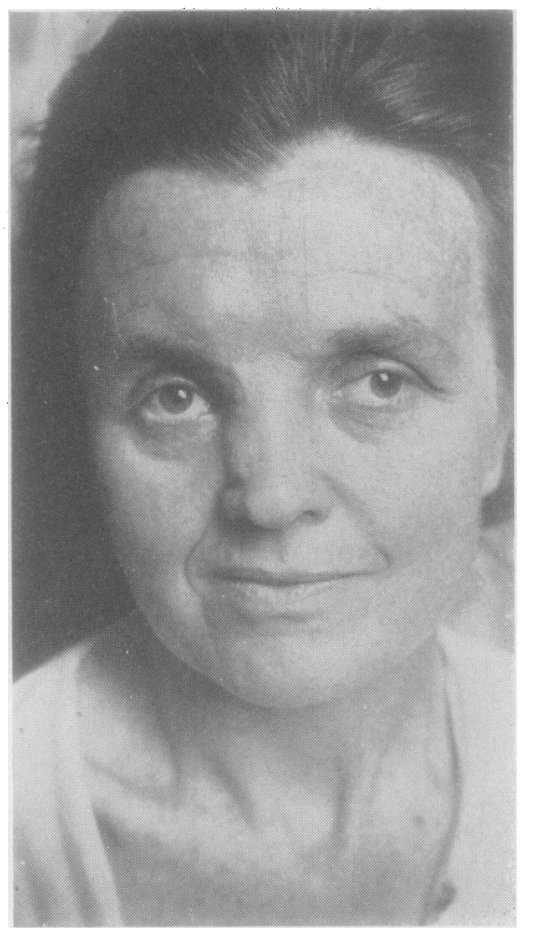

FIG. 1.-Patient's appearance at examination.
A single female housekeeper, aged 42, attended on May 25, 1951, with no complaint except a request for reading-glasses.

History.-Her left eye, she said, had been blind from birth. There had been no headaches nor vomiting. Recently she had had one large " semitumour" removed from the skin just beside the bridge of the nose (Fig. 1), and another from the side of her neck, because, she said, they had been getting noticeably larger during the last 2 years, although not painful. No biopsy had been made of these tumours.

Examination.-There was no proptosis, and no visible or palpable nodule or mass in the eyelids or orbits. Extra-ocular movements were normal. The left eye was divergent and quite blind. The pupils were equal and the right reacted to light and accommodation. Vision in the right eye was $6 / 12$ partly and $J 3$ with correction. There was bilateral primary optic atrophy, more marked in the left eye. The retinal vessels were of normal calibre in the right eye, uniformly thinned in the left. The fundi were otherwise normal. Intra-ocular tension was $20 \mathrm{~mm}$. Hg Schiötz in the right eye and $28 \mathrm{~mm}$. in the left. Transillumination was clear. Slit-lamp examination of the anterior segments showed them to be normal.

* Received for publication February 21, 1952. 


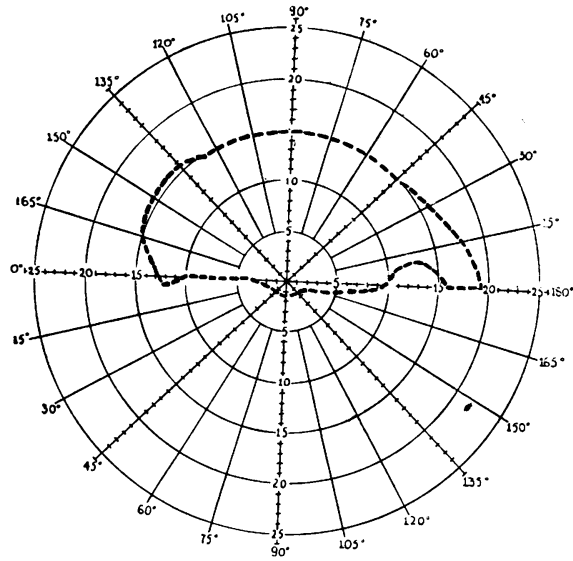

Fig. 2.-Field of vision of right eye.

The field of vision of the right eye (Fig. 2) showed a clear-cut altitudinal hemianopia, with loss of the lower half of the field and sparing of the macula.

General Appearance.-The patient was small, five feet in height, and $7 \mathrm{st} .10 \mathrm{lb}$. in weight, but of normal build and physique. Her head was large for her size with a high forehead (the circumference being 23 " and occiput to nasion 14"): an $x$ ray of the cranium, including the sella turcica, was normal. Distribution of axillary and pubic hair normal.

Skin.-This was deeply freckled all over the trunk and limbs and there were several large café-au-lait patches, the largest being on the right breast $\left(3 \times 1 \frac{1}{2}\right.$ "), on the mons, and on the right thigh ( 2 " diameter). There were several skin nodules on the back of the head and neck, and one on the back (Fig. 3), and some subcutaneous nodules on the course of the superficial nerves of the forearm. These changes had been present for as long as she could remember, had not progressed except for that on the nose mentioned above, and had never been painful.

Biopsy.-Pathological report on specimens excised from neck and forearm :

From forearm: firm, homogeneous white tissue, $1 \times 0.5 \mathrm{~cm}$;

From back of neck: firm, rounded, homogenous white tissue, $1 \times 0.5 \mathrm{~cm}$.

Microscopy of both: neurofibroma.

Central Nervous System.-Apparently normal, except for a lower facial weakness on the left side, where the nasolabial fold was less marked (Fig. 1). The abdomen was rather flaccid and its upper reflexes not elicited.

Hearing.-Confirmed as normal by an otological colleague.

Heart and Chest.-Normal. Blood pressure 160/100.

Laboratory Investigations.-Urine analysis clear. Fluid intake and output records normal over several days. Glucose tolerance test normal.

No evidence of Cushing's syndrome.

Mantoux test faintly positive. Wassermann reaction and Kahn test negative both for blood and cerebrospinal fluid. 
Blood count: haemoglobin 100 per cent., red blood corpuscles 5,000,000 per cmm., colour index 1.0, white blood corpuscles 4,500 per $\mathrm{cmm}$.

Lumbar puncture: clear cerebrospinal fluid, at a pressure of $100 \mathrm{~mm}$. with no alteration in its pressure from pressing the internal jugular vein; cells not in excess of normal, globulin-negative, protein $20 \mathrm{mg}$. per $100 \mathrm{ml}$.

Progress.-During the $\mathbf{1 0}$ months since she was first seen the patient's condition has remained unchanged. This is an undoubted case of neurofibromatosis, the manifestations of which probably showed in infancy, and have been stationary since, apart from the recent tumour growth on the face. The ocular complication may be caused by intracranial glioma of the optic nerves at the chiasmal region, or by pressure downwards on to the chiasm from a cerebral glioma. As her family live in different parts of the country, it has not been possible to interview them, but from their letters it appears that she is the only member affected.

\section{Discussion}

Neurofibromatosis is so diverse in its manifestations that it is small wonder that many medical text-books scarcely mention the eyes. The ocular complications are set out lucidly in the articles of François (1948) and Bloch (1948), who list three ways in which it may show itself:

(i) swellings on the eyelids, due to neurofibromata on the terminals of the fifth nerve, or in the orbit, due sometimes to tumours on the oculomotor nerves (Samuels, 1932), sometimes to an intra-orbital glioma of the optic nerve;

(ii) osseous manifestations, shown by absence of part of the orbital roof (Peyton and Simmons, 1946), so that proptosis, sometimes pulsating, can be produced, despite the fact that the optic disks are normal;

(iii) three kinds of intra-ocular effects:

(a) lesions in the mixed mesodermal-neurogenic tissue of the choroid, which can cause buphthalmos or glaucoma (Foster and Polson, 1934; Kreibig, 1949);

(b) retinal lesions, small isolated areas as described by Bloch (1948);

(c) effects on the optic disk: occasionally tumour formations, of which only a few cases have been reported (Goldsmith, 1949; Stallard, 1938); more often primary optic atrophy seen as an indication of glioma of the optic nerve, or papilloedema, due either to primary optic-nerve involvement (Stern, 1937), or to increased intracranial pressure where cerebral or eighth nerve lesions have existed (Gardner and Frazier, 1930; Penfield and Young, 1930).

A “ central" form of neurofibromatosis is recognized by several writers, including Lichtenstein (1949), and Kinnier-Wilson (1940). It is even possible that most cases of glioma of the optic nerve, whether chiefly intraorbital with proptosis, as in the cases of Gomes (1941, cited by Dresner and Montgomery, 1949), or intracranial with chiasmal involvement, are merely one sign of the disease. Lichtenstein (1949) says:

The disease is so variable, however, that classification is virtually impossible, but certain important features must be recognized. In the universal form, cutaneous lesions, tumours in the central and peripheral nervous systems, and bony changes, are evident. In the classic form, cutaneous lesions and neurofibromata of the peripheral nerves occur with or without bony lesions. Careful study of the central 
nervous system in such instances, however, generally reveals microscopic evidence of the disease. In the central form no superficial evidence of disease may be discernible, that is, the skin may be free of pigmented patches of fibromata and the superficial nerves and nerve trunks may show no focal or diffuse thickenings. The nervous system, however, may show multiple intracranial or intraspinal foci of hyperplasia and neoplasia ... Gliomata of the optic nerves, combined with spongio-blastomata of the brainstem, and other combinations are frequent.

Concerning changes in the field of vision, it is important to recognize that neurofibromatosis can be a cause of primary optic atrophy, without any proptosis, but with hemianopia and a normal sella turcica. Cushing (1930) specifically states that "glioma of the chiasm" is one of the causes of the chiasmal syndrome, and says that six out of his eighteen cases were associated with evidence of generalized neurofibromatosis. He also states that the field defects, though often bitemporal in character as in meningiomata or adenomata of the pituitary, are in gliomata of the chiasm " apt to be bizarre, and hemianopia with a vertical meridian is rare". Davis (1940) says:

gliomata which involve the chiasm and intracranial portion of the optic nerves are less common than the intra-orbital variety ... exophthalmos is usually absent, at least for a time . . . changes in the visual fields in these cases are indispensable for diagnosis.

He points out that since $x$-ray evidence of disease within the sella turcica was not found in either of his cases, " each might have been passed over for an obscure case of atrophy of the optic nerve due to retrobulbar neuritis ", were it not for the "tell-tale signs" of neurofibromatosis. Martin and Cushing (1923) also say that "in such cases we have an explanation for some of the obscure cases of primary optic atrophy". Indeed, it would appear from the literature that in all cases of optic atrophy of obscure origin it is advisable to examine both the patient and other members of the family for any signs of neurofibromatosis.

Besides the field changes, the case here recorded shows one striking feature; whereas many cases of optic-nerve glioma progress rapidly to a fatal conclusion, this eye condition appears to have been stationary for 30 or 40 years. Similar cases have, however, been recorded. Tikhomirov (1947) mentions a 35-year-old woman with neurofibromatosis developing bilateral optic atrophy, of which one side was probably of many years' duration. Davis (1940) describes a 26-year-old person (Case 5), with poor sight since early childhood, in whom a gliomatous tumour of the chiasm was found at operation. Davis also cites van der Hoeve (1925a, b, 1933) as having recorded a case (a woman aged 37 with neurofibromatosis who had had poor sight since childhood) in which intracranial operation revealed involvement of the optic nerve. Davis (1940) comments on the occasional slow progress of failure of vision in these cases of neurofibromatosis and quotes Martin and Cushing (1923) as stating that:

one is forced to consider the possibility that there may be gliomas of different typesrelatively malignant and relatively non-malignant varieties of what Hudson terms gliomatosis. 


\section{Summary}

A case is reported of bilateral optic atrophy with altitudinal hemianopia in neurofibromatosis. The condition is probably quite stationary. The

literature is reviewed.

\section{REFERENCES}

Bloch, F. J. (1948). Arch. Ophthal., Chicago, 40, 433.

CusHiNG, H. (1930). Ibid., 3, 704.

DAVIS, F. A. (1940). Ibid., 23, 735, 957.

Dresner, E., and Montgomery, P. A. D. (1949). Quart. J. Med., 18, 93.

Foster, J., and Polson, C. (1934). Proc. roy. Soc. Med., 27, 1124.

François, J. (1948). Ann. Oculist., Paris, 181, 753.

Fulton, F. J. (1929). New Engl. J. Med., 200, 1315.

Gardner, W. J., and Frazier, C. H. (1930). Arch. Neurol. Psychiat., Chicago, 23, 266.

Goldsmith, J. (1949). Arch. Ophthal., Chicago, 41, 718.

GoMes, J. P. (1941). Amer. J. Ophthal., 24, 1144.

Kreibig, W. (1949). Klin. Mbl. Augenheilk., 114, 428.

Lichtenstein, B. W. (1949). Arch. Neurol. Psychiat., Chicago, 62, 822

Martin, P., and Cushing, H. (1923). Arch. Ophthal., N. Y., 52, 209.

Michel (1873). v. Graefes Arch. Ophthal., 19 (pt. 3), 145. Cited by Davis, 1940

Penfield, W., and Young, A. W. (1930). Arch. Neurol. Psychiat., Chicago, 23, 320.

Peyton, W. T., and Simmons, D. R. (1946). Ibid., 55, 248.

Samuels, B. (1932). Arch. Ophthal., Chicago, 7, 868.

Smith, R. W. (1849). "A Treatise on the Pathology, Diagnosis, and Treatment of Neuroma". Dublin. Summarized by Fulton (1929).

Stallard, H. B. (1938). British Journal of Ophthalmology, 22, 11.

Stern, R. O. (1937). Proc. roy. Soc. Med., 30, 1096.

TikHOMirov, P. E. (1947). Vestnik Oftal., 26, No. 4, p. 25.

VAN Der Hoeve, J. (1925a). Amer. J. Ophthal., 8, 101. (1925b). v. Graefes Arch. Ophthal., 115, 355. (1933). J. belge Neurol. Psychiat., 33, 752

Wilson, S. A. Kinnier (1940). "Neurology", ed. A. N. Bruce. Arnold, London. 